\title{
Who Backs Up Credence Claims? Roles for Government as a Competent Authority in Assuring Quality Attributes
}

\author{
J.D. Noonan and P.J. Batt \\ Curtin University \\ Perth \\ Australia \\ J.D. Warren \\ Department of Agriculture and Food Western Australia \\ South Perth \\ Australia
}

Keywords: credence attributes, food safety, environment, extrinsic quality, sustainable production

\begin{abstract}
The role of government and intergovernmental mechanisms to assure food safety is well established. However, government also has a role in establishing and verifying a range of acceptable production approaches and consequential outcomes relating to credence attributes. The role of government in providing baseline information on the supply side and competent inspection services to verify the effectiveness of control measures at the production and processing levels of the value chain is identified. A meta-accreditation process, whereby government endorses various food safety and quality certification schemes that are coupled with credence attribute assurances is the most cost effective mechanism for government to pursue.
\end{abstract}

\section{INTRODUCTION}

The role of government and intergovernmental mechanisms in assuring food safety is well established. For over a century, foodstuffs have been subjected to government inspection and regulation in terms of biological, chemical and physical contaminants and to simple and obvious quality characteristics such as weights and volumes of finished product (Batt et al., 2006). While intrinsic quality characteristics are often used to describe the visible physical characteristics of products (Noonan, 2004), many intrinsic quality characteristics are considered commercially sensitive and are only released to potential suppliers after initial commercial negotiations.

Food safety and customer specified quality certification is increasingly becoming a prerequisite for market access. Batt et al. (2006) discuss a number of major food borne illnesses, intentional and unintentional contaminations, substitution of raw materials and or labels, and a range of other misleading or fraudulent activities. Consequently, value chains around the world are being examined more stringently by consumers (Lamb, 2009; Roberts, 2008; Weber, 2009); governments (Batt et al., 2006; Codron et al., 2005a\&b; Pierson, 2004); and end customers in the retail and hospitality, restaurant and institutional sectors (Fulponi, 2005; Klieber, 2007; Newton, 2007). Market research indicates that customers continue to signal an increasing demand for credence attributes through mainstream value chains (Gelhar and Regmi, 2005; King and Venturini, 2005) and retailers are responding (Coles Group, 2009; Tesco, 2009; Wal-mart, 2008). 
Collectively, these factors, coupled with a rise in consumers' discretionary income, have resulted in an increase in the importance of credence factors or extrinsic quality characteristics. In addition, there is a growing public expectation that farming communities should use the resources that they manage to produce personal profit, in a manner that is responsible and which reflects broader community values (Noonan et al., 2008). There is anecdotal evidence that the growth in farmers markets' is focusing attention on the authenticity, safety and source of product within such markets.

For exporters of horticultural products and fresh and perishable foods, many of which are produced in the transitional economies, the rise in credence attributes has major implications for suppliers and the value chain (Humphrey, 2005). For major exporters of commodities (grains and oilseeds), the market signals for credence attributes are either niche based or weak (Noonan et al., 2008; WAFF, 2006). However, food miles, countryof-origin labelling and local sourcing endeavours are likely to impact on all exporters. Batt and Noonan (2009) report that these issues may be regional and/or trade area specific. Southern hemisphere horticultural exporters in particular, have attempted to influence the mechanisms by which importers have sought to seek assurances on a range of attributes (Adonis, 2005).

Much of the focus on credence attributes has been on tropical and sub-tropical horticultural products. Brand and certification marks such as: Fairtrade (Lamb, 2009); Forest Stewardship Council (FSC, 2009); and a range of organic (IFOAM, 2006a\&b) and welfare certifications and participatory guarantee arrangements, have been developed with the transitional nations as the intended beneficiary (Henson and Reardon, 2005; Jaffee and Masakure, 2005; UNCTAD, 2007a\&b). In many instances, these branding and certification arrangements have been undertaken by NGOs or by actors directly participating in the value chain. The Sustainable Agriculture Platform (SAI) is an example of mid chain actors collaborating to characterize and quantify a range of credence attributes and provide guidance relating to production systems, products and outcomes (SAI, 2009).

\section{THE ROLE OF GOVERNMENT}

The role of government has evolved over the past two decades. At the local, state, provincial and national levels, the evolution has often been away from that of setting and inspecting food safety standards to setting and verification of food safety outcomes (Martin et al., 2003; Walker et al., 2003: Yapp and Fairman, 2006). At an international level, governments have been central to a number of intergovernmental health and safety and trade related institutions. The United Nations World Health Organizations joint sponsored body, the Codex Alimentarius Commission, is the most influential organisation in respect to food safety (OECD, 2005). Batt et al. (2006) identify that cross-border supply chain partners have to deal with local and international trade regulations, complex logistics networks, and differing levels of competency and technology. As there are no directly analogous intergovernmental processes or organizations with a focus on credence attributes, there has been a move by value chain actors to introduce a range of commercial assurance mechanisms.

There is considerable evidence of the potential impact of quality assurance measures as a barrier to food exports from the developing world (Dolan and Humphrey, 2004; Garcia-Martinez and Poole, 2004; Humphrey, 2005). In addition, economic growth and consumer demand has attracted the world's major retailers to the developing countries where their procurement strategies are instrumental in transforming supply 
chains (Batt et al., 2006). Therefore, local governments, donors and NGOs need to consider policies aimed at enhancing the ability of smallholder farmers to compete in modern retail chains and to access export markets.

\section{Certification and Recognition Mechanisms for Credence Attributes}

There are numerous mechanisms through which certification or recognition of credence attributes can be provided. The European Commission's (EC) Eco-Management and Audit Scheme (EU, 2009) is a management tool for companies and other organisations to evaluate, report and improve their environmental performance. The scheme has been available since 1995 and was originally restricted to companies in industrial sectors. A range of programs have since evolved in Europe, either directly or indirectly under the auspices of the EC. Programs, such as the European Initiative for Sustainable Development in Agriculture (EISA) provide primary producers, agribusiness and the food sector with a capacity to claim certain credence attributes (EISA, 2009). A number of other commercial mechanisms have evolved over the past decade including GlobalGAP.

While eco-labels inform buyers at the point-of-sale about one, some or almost all ecological impacts of the product during its life cycle, the purpose of environmental labelling is to help buyers make a distinction between competing product alternatives and to presumably choose the least environmentally damaging option (Cole and Harris, 2003). However, Polonsky et al. (2005) suggest that the terms eco-friendly and other similar claims are difficult to substantiate. They suggest that eco-friendly is not a major influence in the consumer's decision to purchase food, finding that eco-friendly is unlikely to be successful until consumers value eco-friendly food attributes. The challenge therefore, is when consumers value eco-friendly or other sustainable attributes, who will they seek out as credible authorities? Representatives of prominent NGOs have indicated that they are unwilling to undertake such roles (McLellan, 2005), preferring to operate under collaborative arrangements via multi-party umbrella bodies such as the International Social and Environmental Accreditation and Labelling (ISEAL) Alliance (ISEAL, 2009).

\section{DISCUSSION}

Curtin University, with collaborating partners around the world, undertook a major study of Global Trends in Food Safety and Quality for the Australian Government between 2005 and 2006 (Batt et al., 2006). The findings of the Global Trends study as they relate to horticulture were reported by Batt and Noonan (2009). However, it is important to note that: (1) the factors that determine the extrinsic quality attributes of goods and services is largely the domain of the value chain and collaborating parties including certification agencies; and (2) in certain circumstances, there a number of roles for government. First, there is a need to validate and verify the various credence attributes. Examples of validation and verification include a determination of acceptable environmental off-site impacts of primary production and processing; conditions and pay levels for workers; and intergovernmental agreements on trade related matters.

Participants in the value chain study indicated that government had a role in establishing and verifying a range of acceptable production approaches and consequential outcomes (Batt et al., 2006). We contend that there is a role for government in providing baseline information on credence attributes on the supply side through Current Recommended Practices (CRPs) (Clifton et al., 2004) and GAP/GMP. This is part of the role of a competent authority or honest broker in verifying the effectiveness of control 
measures through the value chain. Seymour et al. (2007) provide a sustainable production or triple bottom line certification approach, outlined as a staged or tiered approach, which enables primary producers to join food safety and quality systems that utilise Environmental Management System (EMS) approaches.

From 2001 to 2003, the government of Western Australia identified that credence attributes could become a factor with the potential to exclude WA primary producers from gaining or continuing to access domestic and export markets. The Farming for the Future Initiative was instigated by government to address the potential (DAFWA, 2009). With this background, the Department of Agriculture and Food WA (DAFWA) explored the potential roles for government in providing sustainable practice and product certification.

Through the work of Batt et al. (2006) and a desk top analysis by Noonan and Warren (2008b), it was revealed that there were no mechanisms available in the public domain that could provide WA primary producers with a suitable step-wise or tiered approach towards demonstrating their progress towards more sustainable production. Such a mechanism would need to combine food safety and intrinsic and extrinsic quality assurance, while taking a rigorous and verifiable approach to assessing both product and process impacts (externalities) and outcomes.

The model or framework outlined in Table 1 is indicative of the key functions of a stepped or tiered approach from self assessment to fully independent third party certification against an acceptable standard, within an overarching meta-accreditation of standards and systems. Under this framework, government provides a formal recognition of programs that meet identified criteria. Such an approach enables government to recognise programs that meet criteria established at a base level through means of SelfAssessment Tools (England et al., 2008) or the like.

At the first level or tier, the primary producer completes a self assessment and submits it for assessment. If the assessment criteria are deemed to be in place, and the primary producer has committed to moving to the second tier, then a first tier certificate is issued by government.

At the second tier, the base level requirements (tier one) are built upon. Firstly, through the primary producer enabling a continuous improvement approach, consistent with those outlined under the ISO family of standards (ISO, 2004); and secondly, by gaining independent certification against a suitable standard that is consistent with the frameworks requirements. There are commercial, grower group and industry programs in Australia that enable peer based review, many of which borrow from numerous local and overseas quality assurance programs.

At the third tier, third party assessment must be undertaken by a fully independent organization. Such an organization should operate under the auspices of a credible international structure such as the International Accreditation Forum (IAF, 2009). In Australia, this would lead to organisations or certification bodies (audit companies) that operate under the accreditation requirements of the Joint Accreditation System for Australia and New Zealand (JAS-ANZ) for compliance against either ISO Guide 62 process certification (ISO, 1996a) or preferably against Guide 65 - product certification (ISO, 1996b).

A key determinant of this process is verification by government and the supply chain of the triple bottom line outcomes. These may occur at the industry, regional or provenance level. A range of government agencies, encompassing agricultural production 
economic and rural development; environmental protection; health; housing; quarantine; and others, could contribute to the verification process.

However, governments worldwide are conscious of the cost of service provision. Based on a desk top study, supported by data from a horticultural environment assurance project in WA (Foord et al., 2010), the cost of government providing a full credence attribute certification service, which assumes a food safety and intrinsic quality certification is already in place, was estimated to cost AUD 1000 per enterprise per year (Noonan and Warren, 2008b). It is unlikely that government would be in a position to fund such a cost from within its resources, unless there were considerable calls to do so. In WA, it is possible to recoup such a cost through a range of fee-for-service mechanisms. However, the potential to use such mechanisms would depend on the acceptability and agreement of those who would be required to pay the fee for the service. Historically, primary producers and actors in value chains have been reluctant to pay the full cost of such services. Therefore, antipathy towards the recovery of costs further justifies a metaaccreditation approach.

Conversely, under a meta-accreditation process, whereby government endorses various food safety and quality certification schemes that are coupled with credence attribute assurances, the cost is estimated to be in the order of AUD 30-50 per enterprise per year (Noonan and Warren, 2008b). Government and the value chain are likely to be predisposed to such an insignificant direct cost. The cost of the verification components (e.g. air borne dust monitoring; checks on provenance claims and labelling compliance; stream water turbidity testing; and worker welfare) within the framework is likely to be highly variable from industry to industry, location to location, and year to year.

\section{CONCLUSION}

From a management perspective, a meta-accreditation approach reduces: (i) the number of audits and related activities at the individual business level; (ii) a range of transaction costs; and (iii) inherently reduces the overall demand for competent auditors who are likely to be in short supply.

While a meta-accreditation approach appears well suited in the more advanced economies, the potential for such an approach in the transitional and emerging economies warrants further investigation and discussion.

\section{Literature Cited}

Adonis, R. 2005. A proposal for realistic approach for harmonization within the fresh produce sector. CIES, Southern Hemisphere Association of Fresh Fruit Exporters.

Batt, P.J, Noonan, J.D and Kenyon, P. 2006. An analysis of global trends for food safety and quality management for the Australian food industry. Department of Agriculture, Fisheries and Forestry. Canberra.

Batt, P.J. and Noonan, J.D. 2009. Global trends $n$ food quality: An exploratory study in fresh produce supply chains. Acta Hort. 831: 95-104.

Clifton, C., McGregor, C., Standen, R. and Fritisch, S. 2004. Current Recommended Practices: A directory for broad acre dryland agriculture. Watermark Project. Murray Darling Commission. Canberra.

Codron, J-M., Giraud-Heraud, E. and Soler, L-G. 2005a. Minimum quality standards, premium private labels and European meat and fresh produce retailing, Food Policy 30(3): 270-283. 
Codron, J-M., Grunert, K., Giraud-Heraud, E., Soler, L-G. and Regmi, A. 2005b. Retail sector responses to changing consumer preferences - The European experience, Agriculture Information Bulletin, USDA, No. 794: 32-46.

Cole, A. and Harris, J. 2003. Eco-labelling, credence attributes and the role of government. Department of Primary Industry, Victoria.

Coles Group. 2009. Coles Group: Codes of Practice - Ethical Sourcing.

DAFWA. 2009. Farming for the Future.

Dolan, C. and Humphrey, J. 2004. Changing governance patterns in trade in fresh vegetables between Africa and the United Kingdom. Environment and Planning 36: 491-509.

EISA. 2009. European Initiative for Sustainable Development in Agriculture. www.sustainable-agriculture.org/

England, D.R., Ashley-Jones, R., Noonan, J.D. and Warren, J.D. 2008. Farming for the Future: Self-Assessment Tool. Western Australian Agricultural Authority. Bulletin 4694.

European Commission 2009. What is EMAS? ec.europa.eu/environment/emas/index_en.htm

Foord, G., Murphy-White, S. and Noonan, J.D. 2010. Walking the walk on environmental assurance: a case study of vegetable growers in Western Australia [this issue]

FSC. 2009. Forest Stewardship Council: www.fsc.org/

Fulponi, L. 2006. Private voluntary standards in the food system: The perspective of major food retailers in OECD countries. Food Policy 31 (2006): 1-13.

Garcia-Martinez, M. and Poole, M. 2004. The development of private fresh produce safety standards: Implications for developing Mediterranean countries. Food Policy 29: 229-255.

Gelhar, M. and Regmi, A. 2005. Factors shaping global food markets, Agriculture Information Bulletin, USDA, No. 794: 5-17.

Henson, S. and Reardon, T. 2005. Private agri-food standards: Implications for food policy and the agri-food system. Food Policy 30(3): 241-253.

Humphrey, J. 2005. Shaping value chains for development: global value chains in agribusiness. Report prepared for GTZ-Project Shaping Value Chains for Development. Institute of Development Studies, University of Sussex, UK.

IAF. 2009. What is the International Accreditation Forum? www.iaf.nu/

IFOAM. 2006a. Participatory guarantee systems - Case Studies from Brazil, Canada, India and the USA. IFOAM Bonn. www.ifoam.org

IFOAM. 2006b. Organic agriculture and participatory guarantee systems marketing and support for organic smallholders. IFOAM Bonn. www.ifoam.org

ISEAL. 2009. The International Social and Environmental Accreditation and Labelling Alliance. www.isealalliance.org

ISO. 1996a. ISO/IEC Guide 62:1996: General requirements for bodies operating assessment and certification/registration of quality systems. International Standards Organisation. www.iso.org/iso/home.htm

ISO 1996b. ISO/IEC Guide 65:1996: General requirements for bodies operating product certification systems. International Standards Organisation. www.iso.org/iso/home.htm

ISO. 2004. ISO 14001. Environmental management systems - Requirements with guidance for use. www.iso.org/iso/catalogue_detail?csnumber $=31807$ 
Jaffee, S. and Masakure, O. 2005. Strategic use of private standards to enhance international competitiveness: Vegetable exports from Kenya and elsewhere. Food Policy 30: 316-333.

King, R.P. and Venturini, L. 2005. Demand for Quality Drives Changes in Food Supply Chains. Agriculture Information Bulletin, USDA, No. 794: 18-31.

Klieber. A. 2007. What does the future hold for producers and packers? A Coles View. In: Keep it Real. Proc 5th Australian On-Farm QA and $5^{\text {th }}$ Australian EMS in Agriculture Conference. TQA. Hobart.

Lamb, H. 2009. Fighting the Banana Wars and Other Fairtrade Battles. Rider Books. London.

McClellan, R. 2005. Closing remarks at taking stock and moving forward. Agricultural Sustainability Assurance \& Environmental Management Systems Practitioners Symposium and Workshop. Farming for the Future. Department of Agriculture and Food WA. Perth.

Martin, T., Dean, E., Hardy, B., Johnson, T., Jolly, F., Mathews, F., McKay, I., Souness, R. and Williams, J. 2003. A New Era for Food Safety Regulation in Australia, Food Control 14: 423-429.

OECD. 2005. Private standards and developing country access to global supply chains. OECD. Paris. [AGR/CA/APM(2005)26].

Newton. S. 2007. Retailer requirements for supply chain assurances: A Metcash view. In: Keep it Real. Proc 5th Australian on Farm QA and $5^{\text {th }}$ Australian EMS in Agriculture Conference. TQA. Hobart.

Noonan, J.D., Warren, J.D. and Rivers, M. 2008. What are the production and product attributes that producers will be asked to prove? Credence attribute assurances: Institutional, domestic and export market demand and the capacity of Western Australian primary producers to deliver. Sustainable Agricultural Practices Green Paper No 1. Department of Agriculture and Food WA. Perth.

Pierson, M. 2004. Managing food safety with global hazards - The implications of BSE for global trade and public health. Proceedings of the $11^{\text {th }}$ Australian HACCP Conference. Adelaide.

Polonsky, M.J., Bhaskaran, S. and Cary, J. 2005. Exploring the opportunities for sustainable food labelling - A supply chain perspective. Proceedings ANZMAC 2005: 184-190.

Roberts, P. 2008. The End of Food. Bloomsbury, London.

SAI. 2009. The Sustainable Agriculture Initiative (SAI) Platform. www.saiplatform.org/

Seymour. E.J., Ridley. A.M. and Noonan, J.D. 2007. Assessing the role of a four stage approach for improving the compatibility of Environmental Management Systems and Quality Assurance. Aust. J. Exp. Agric. 47(3): 333-345.

TESCO. 2009. Tesco Natures Choice. www.tescofarming.com/tnc.asp

UNCTAD. 2007a. The implications of private-sector standards for good agricultural practices exploring options to facilitate market access for developing-country exporters of fruit and vegetables: Experiences of Argentina, Brazil and Costa Rica. UNCTAD/DITC/TED/2007/2.

UNCTAD. 2007b. Challenges and opportunities arising from private standards on food safety and environment for exporters of fresh fruit and vegetables in Asia: Experiences of Malaysia, Thailand and Viet Nam. UNCTAD/DITC/TED/2007/6

UNCTAD. 2008. Making sustainability standards work for small-scale farmers. A PreUNCTAD XII Event. www.unctad.org/trade_env/meeting.asp?MeetingID=249 
Walker, E., Pritchard, C. and Forsythe, S. 2003. Hazard Analysis Critical Control Point and prerequisite program implementation in small and medium size food businesses. Food Control 14: 75-793.

Wal-Mart. 2008. Wal-Mart Promotes Sustainable Agriculture. walmartstores.com/media/factsheets/fs_2307.pdf

Weber, K. 2009. Food Inc: how industrial food is making us sicker, fatter, and poorer and what you can do about it. PublicAffairs, New York.

Yapp, C. and Fairman, R. 2006. Factors effecting food safety compliance within small and medium-sized enterprises: implications for regulatory and enforcement strategies. Food Control 17: 42-51.

\section{Table 1: A four step approach to integrate food safety, quality and environmental assurance}

\begin{tabular}{|c|c|c|}
\hline & Quality Assurance Scheme & EMS \\
\hline Stage One & $\begin{array}{l}\text { Vendor Declarations } \\
\text { - Based on National Vendor } \\
\text { Declarations (NVD's) }\end{array}$ & $\begin{array}{l}\text { Beginners Guide to Environmental } \\
\text { Awareness } \\
\text { - Self-assessment } \\
\text { - No audit }\end{array}$ \\
\hline Stage Two & $\begin{array}{l}\text { National On-Farm QA System } \\
\text { FreshCare }{ }^{\mathrm{TM}} \text { ASEAN GAPs } \\
\text { Requires 3rd party audit for certification }\end{array}$ & $\begin{array}{l}\text { Environmental Farm Plan } \\
\text { Plan-do-check-review cycle } \\
\text { - Self-assessment, environmental } \\
\text { review, action plan. } \\
\text { - Self-audit }\end{array}$ \\
\hline $\begin{array}{l}\text { Stage } \\
\text { Three }\end{array}$ & $\begin{array}{l}\text { SQF1000 }{ }^{\mathrm{CM}} \text { level } 1+\mathrm{REP} \text { module } \\
\text { or GlobalGAP }{ }^{\circledR} \\
\text { Requires } 3 \text { rd party audit for } \\
\text { certification. }\end{array}$ & $\begin{array}{l}\text { Industry EMS } \\
\text { Full EMS but not 3rd party audit }\end{array}$ \\
\hline Stage Four & $\begin{array}{l}\text { SQF1000 }{ }^{\mathrm{CM}} \text { level } 2 / 3+\text { Responsible } \\
\text { Environmental Practice (REP) module } \\
\text { - } \quad \text { Global Food Safety Initiative } \\
\text { Systems compliance \& based on } \\
\text { HACCP Certification. }\end{array}$ & $\begin{array}{l}\text { Certified to ISO14001 } \\
\text { - As for Level } 3 \text { plus 3rd party } \\
\text { JAS-ANZ audit and demonstrated } \\
\text { compliance with legal obligations and } \\
\text { policy } \\
\text { Certification }\end{array}$ \\
\hline
\end{tabular}

Source: Adapted from Seymour et al (2007). 